\title{
Notes on the vocalizations of Scarlet-rumped Cacique (Cacicus microrhynchus)
}

Peter Boesman

In the following we briefly analyze and compare voice of the two races of Scarlet-rumped Cacique (Cacicus microrhynchus). We also try to quantify the extent of any vocal differences using the criteria proposed by Tobias et al. (2010), as a support for taxonomic review. We have made use of sound recordings available on-line from Xeno Canto (XC).

Both races typically emit well-spaced single whistles and much faster rattling series of notes. A comparison of song-like vocalizations, illustrated with sonograms:

\section{$\underline{\text { Race pacificus }}$}

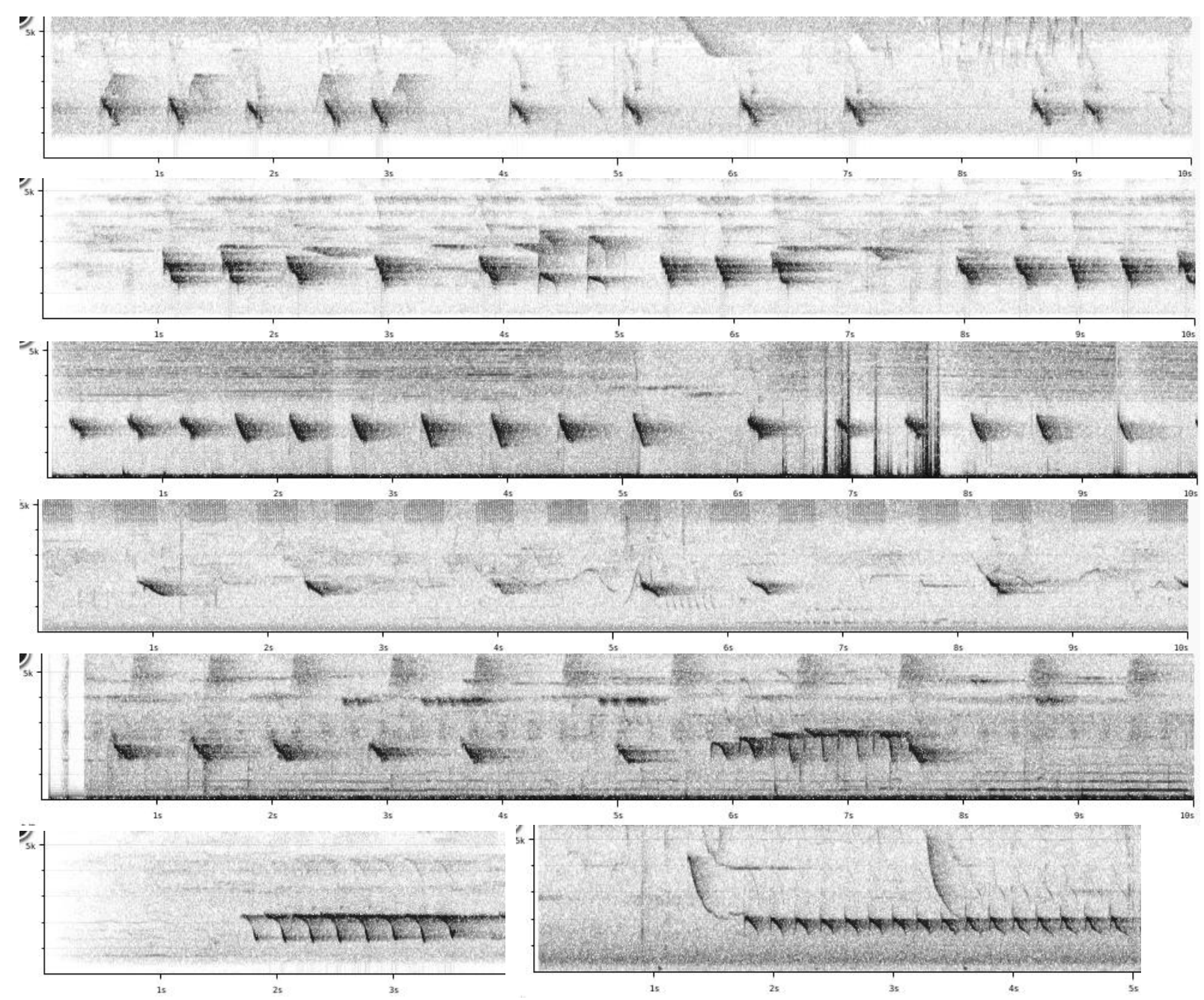


HANDBOOK OF THE

Alive ORNITHOLOGICAL NOTES

nominate

Honduras

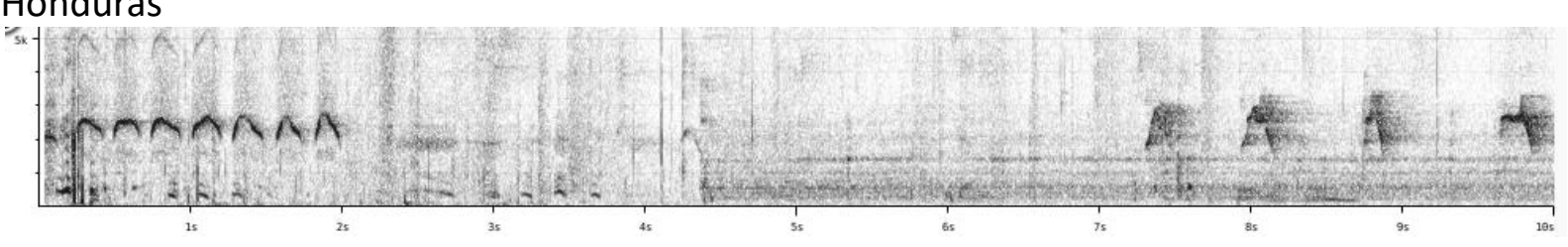

Costa Pica
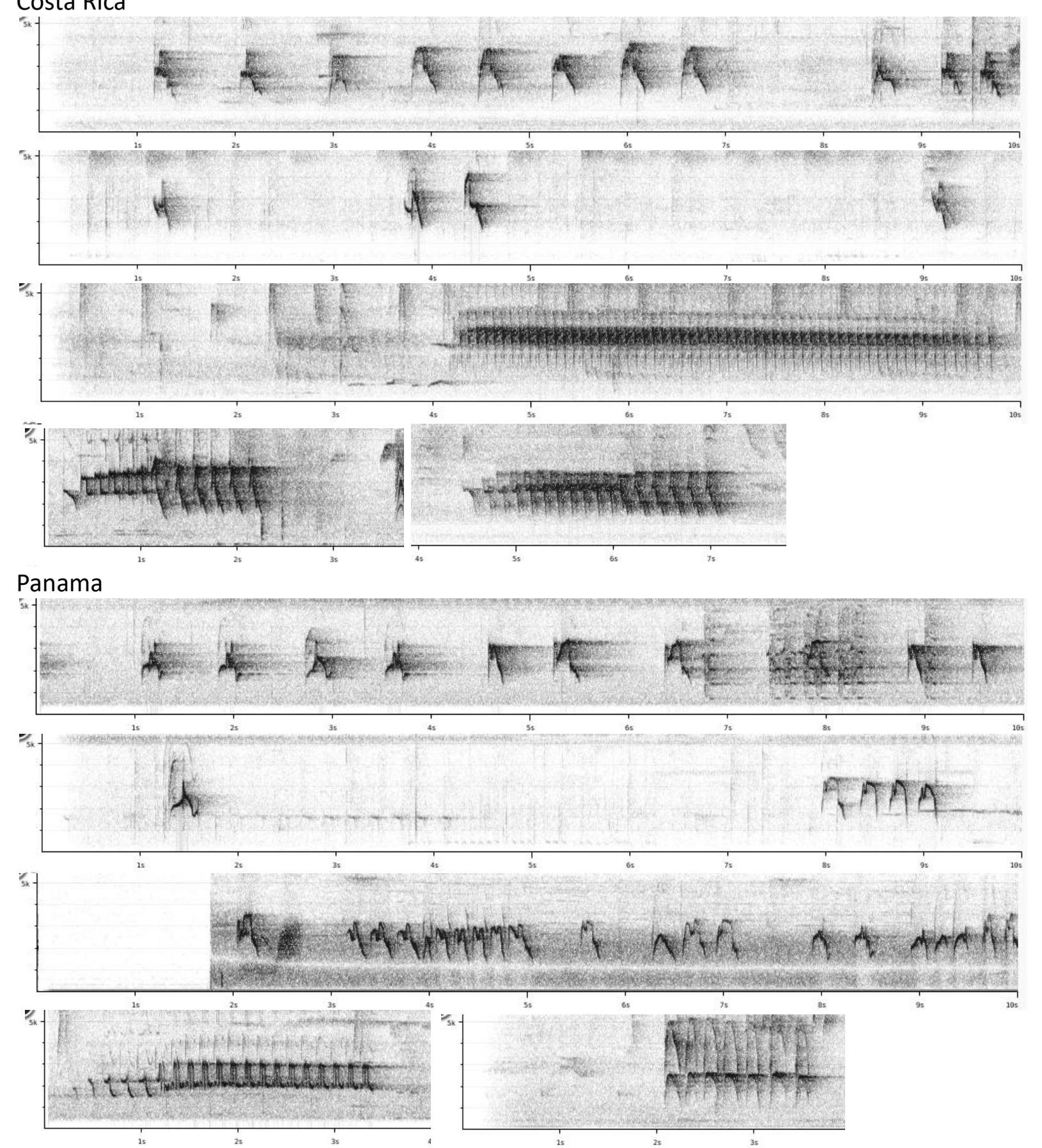

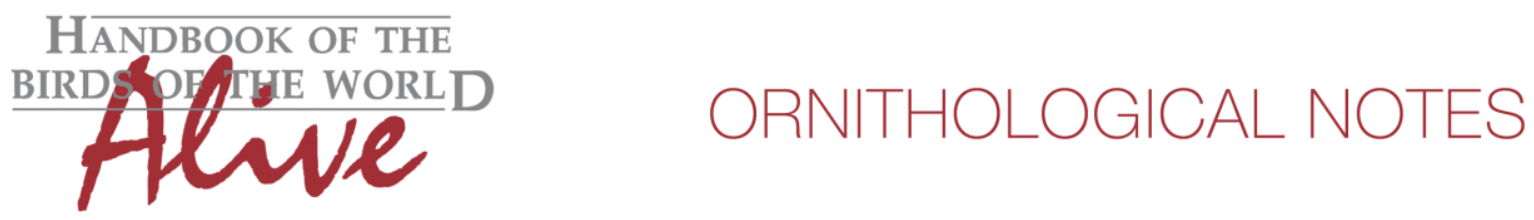

Vocal difference between the two races is quite obvious in all homologous vocalizations:

* single notes:

nominate: irregularly overslurred notes reaching max. frequency of $3.2-4 \mathrm{kHz}$ pacificus: principally downslurred notes reaching max. frequency of $2.2-2.6 \mathrm{kHz}$

* fast rattling series:

A similar difference in max. frequency and nominate often combines two series of different repeated notes.

Based on nominate's much higher max. frequency (score 2-3) and different note shape (irregularly overslurred vs principally downslurred)(score 1), application of Tobias criteria would lead to a total vocal score of 3-4.

More recordings are desirable from Colombia and eastern Panama, to have a better understanding of vocal change in the area of contact.

This note was finalized on 24th June 2016, using sound recordings available on-line at that moment. We would like to thank in particular the many sound recordists who placed their recordings for this species on XC.

\section{References}

Tobias, J.A., Seddon, N., Spottiswoode, C.N., Pilgrim, J.D., Fishpool, L.D.C. \& Collar, N.J. (2010). Quantitative criteria for species delimitation. Ibis 152(4): 724-746.

\section{Recommended citation}

Boesman, P. (2016). Notes on the vocalizations of Scarlet-rumped Cacique (Cacicus microrhynchus). HBW Alive Ornithological Note 369. In: Handbook of the Birds of the World Alive. Lynx Edicions, Barcelona. (retrieved from http://www.hbw.com/node/1252919 on 3 November 2016). 